\title{
PEMBELAJARAN FISIKA DI SMA MELALUI PERTANYAAN (LEARNING BY QUESTIONING) DAN KETERAMPILAN BERPIKIR
}

\author{
Nadi Suprapto ${ }^{*}$, Suliyanah, Setyo Admoko \\ Prodi Pendidikan Fisika Jurusan Fisika FMIPA UNESA \\ ${ }^{*}$ Email: nadi_unesa@yahoo.co.id
}

\begin{abstract}
ABSTRAK
Paradigma pembelajaran saat ini adalah Student Center Learning (SCL), yang dapat dicapai apabila pembelajaran khususnya pembelajaran fisika di SMA dirancang sedemikian rupa hingga dapat membelajarkan siswa. Salah satu desain pembelajaran (learning design) yang dapat digunakan untuk membelajarkan siswa adalah pembelajaran melalui pertanyaan -Learning by Questioning- (LBQ). LBQ berpotensi lebih memberdayakan keterampilan berpikir dan dapat mengkonstruk pengetahuan. Untuk itu sangat perlu dihasilkan contoh perangkat pembelajaran melalui bertanya (LBQ) dan selanjutnya diuji secara empiris. Artikel ini akan mendeskripsikan hasil-hasil pengujian empiris tersebut, sehingga rumusan masalah yang dikemukakan adalah bagaimanakah hasil implementasi perangkat pembelajaran melalui bertanya (LBQ) di kelas? Setelah dihasilkan contoh perangkat pembelajaran melalui pertanyaan (Learning by Questioning) yang terdiri dari dua topik fisika SMA: fluida statis yang sesuai dengan Kurikulum Tingkat satuan Pendidikan (KTSP), dan Hukum-hukum Newton sesuai dengan Kurikulum 2013. Perangkat pembelajaran tersebut terdiri atas silabus, RPP, LKS dan panduannya, buku siswa, Lembar penilaian LBQ dan kuncinya. Selanjutnya terkait hasil uji empiris atau hasil implementasi perangkat pembelajaran di kelas, diperoleh temuan-temuan: (a) Penerapan pembelajaran bertanya (LBQ) dapat meningkatkan keterampilan berpikir siswa dengan perolehan gain peningkatan untuk 10 atribut keterampilan berpikir berada pada rentang 0,27 sampai 0,73 dengan rata-rata 0,48 (sedang), (b) Ditemukan delapan atribut keterampilan berpikir (80\%) dari sepuluh yang diteliti yang konsisten dan dapat ditingkatkan dengan pembelajaran melalui pertanyaan (LBQ). Kedelapan atribut tersebut adalah menganalisis dan mensintesis (analizing and synthesizing), meningkatkan kualitas pertanyaan (raises questions), menggali informasi (information searching), menggunakan konsep (utilizes concept), membuat inferensi (makes inferences), membangun implikasi (generates implications), mengambil keputusan (making decision), dan memecahkan masalah secara kreatif (creative problem solving), (c) Guru model dan siswa merespons positif pembelajaran dengan LBQ. Guru model menilai 95 persen penerapan pembelajaran LBQ sesuai untuk diterapkan, sementara siswa memberikan jawaban positif sebesar $76,7 \%$.
\end{abstract}

Kata Kunci: pembelajaran bertanya, LBQ, fisika, SMA, keterampilan berpikir

\section{Pendahuluan}

Dewasa ini para pendidik (guru) kerap menganjurkan "pemecahan masalah" tetapi jarang kita dengar tentang pentingnya penciptaan masalahmasalah dan pengajuan pertanyaanpertanyaan. Pendidik hanya sebagai pemberi masalah kepada pebelajar bukan pengorientasi masalah. Kerapkali masalah muncul dari guru bukan dari siswa karena kegagalan atau kurang terampilnya selama proses penciptaan masalah tersebut. Padahal, salah satu bagian penting dalam konstruktivisme ialah konstruksi pertanyaan-pertanyaan. Selain para siswa mencoba menjawab 
pertanyaan-pertanyaan atau memecahkan masalah, mereka juga diharapkan termotivasi untuk menciptakan pertanyaan. Menurut Piaget (dalam Dahar, 1988) perumusan pertanyaan-pertanyaan merupakan salah satu bagian yang paling penting dan paling kreatif dari sains yang diabaikan dalam pendidikan sains.

Bertanya bukanlah suatu keterampilan yang mudah bagi pendidik dalam pembelajaran. Tidak mengherankan bermunculan berbagai teknik atau cara bertanya yang terintegrasi dalam pembelajaran mulai hanya sekedar pembukaan pembelajaran sampai disajikan utuh di sepanjang tahapan pembelajaran. Dari serangkaian teknik bertanya khususnya pembelajaran melalui bertanya, pada penelitian ini difokuskan pada 2 jenis pembelajaran melalui bertanya. Hal ini didasarkan pada pengalaman peneliti sebelumnya yang telah melakukan penelitian pembelajaran melalui bertanya tersebut. Pertama adalah pembelajaran melalui serangkaian pertanyaan pemandu (guiding question) (Suprapto, Nadi, 2010a, 2010b), kedua adalah pembelajaran bertanya Sokrates (Socratic Method) (Suprapto, Nadi \& Dwikoranto, 2010).

Temuan penelitian pertama menyatakan pembelajaran melalui serangkaian pertanyaan (pemandu) mampu meningkatkan pemahaman konsep fisika siswa untuk topik-topik fisika modern (Suprapto, Nadi, 2010a). Penelitian tindakan kelas yang dilakukan pada siswa MA Akselerasi Amanatul Ummah Pacet Mojokerto tersebut meningkatkan pemahaman konsep fisika dengan perolehan gain (g) yang tinggi dari setiap siklusnya. Temuan penelitian kedua menunjukkan penerapan guiding question juga meningkatkan kinerja mahasiswa dalam kegiatan praktikum dan meningkatkan pemahaman konsep fisika yang dicapai mahasiswa
(Suprapto, Nadi, 2010b). Pemberian serangkaian pertanyaan pemandu di laboratorium membantu mahasiswa membuka pemahaman awal sebagai pengantar menuju aktivitas laboratorium. Kemampuan mahasiswa digali melalui respon jawaban yang disampaikan. Jawaban benar dijadikan sebagai bekal yang tetap dipegang dalam membuktikan teori dan menemukan temuan baru. Jawaban salah diharapkan sebagai konflik kognitif yang menjadikan pengalaman berharga mahasiswa sehingga pada suatu saat kesalahan konsep fisika tidak akan terulang lagi. Pengalaman akan kebenaran dan kesalahan konsep menjadi bermakna dalam memori jangka panjang (longterm memory) pebelajar. Hal inilah yang menjadi esensi dari teori belajar konstruktivis.

Penelitian lain tentang metode bertanya juga sudah dilakukan pada tingkatan mahasiswa pada mata kuliah sejarah fisika. Hasilnya adalah pembelajaran dengan menerapkan metode bertanya Sokrates (Socratic Method) yang dilakukan membuat mahasiswa dan dosen antusias. Pelaksanaan pembelajaran berpusat pada mahasiswa dan adanya keaktifan dalam belajar. Hasil penilaian terhadap pemikiran kritis mahasiswa menunjukkan lebih dari $60 \%$ jawaban mahasiswa mengarah pada pemikiran Sokrates (Suprapto, Nadi \& Dwikoranto, 2010). Berdasarkan temuan dan hasil penelitian yang telah dilakukan dapat dibuat sebuah konklusi bahwa pembelajaran melalui bertanya (guiding question dan metode Sokrates) meningkatkan pemahaman konsep fisika, kinerja laboratorium, dan mengaktifkan pebelajar.

Hasil penelitian tersebut memetakan keterampilan berpikir siswa SMA/ MA dan mahasiswa untuk pembelajaran fisika. Namun menurut teori perkembangan kognitif Piaget 
(Slavin, 1994), sebenarnya keterampilan berpikir sudah bisa terlihat sejak anak berada pada tahap operasi formal (siswa SMP/MTs), meskipun kurang menonjol. Karakteristik operasi formal diantaranya kemampuan penalaran, berpikir deduktif, berpikir abstrak, pemecahan masalah, dan membuat generalisasi. Sebagian besar siswa SMA baru bisa mencapai karakteristik tersebut. Untuk itu penelitian ini difokuskan pada keterampilan berpikir siswa SMA yang lebih observable dan measureable. Sehingga memudahkannya untuk dioptimalkan pada jenjang perguruan tinggi.

Sementara itu jenis pembelajaran bertanya lainnya yang telah dikembangkan oleh Corebima sejak tahun 1985 adalah pembelajaran berpola PBMP (Pemberdayaan Berpikir Melalui Pertanyaan) atau yang terkenal dengan TEQ (Thinking Empowerment by Questioning) (Corebima, A.D., 2010). Hasil analisis peneliti menunjukkan adanya kemiripan pola-pola pembelajaran TEQ dengan metode Sokrates (Socratic method) dan guiding question. Orientasi dari semua jenis pembelajaran bertanya tersebut adalah membuat pebelajar aktif, kreatif, dan berpikir.

Meskipun terdapat kemiripan pola-pola pembelajaran TEQ dengan metode Sokrates (Socratic method) dan guiding question namun pada masingmasing model pembelajaran memiliki penekanan dan kelebihan yang berbeda. Pada penerapan model pembelajaran dengan metode Sokrates (Socratic method) dan guiding question lebih menekankan pada kualitas proses pembelajaran yang berlangsung yaitu mengutamakan pola komunikasi diskusi dengan memunculkan pertanyaan antara guru dengan siswa dan juga antara siswa dengan siswa. Sedangkan pada model pembelajaran TEQ atau PBMB untuk memunculkan pertanyaan dari siswa dilakukan lebih terstruktur yaitu dengan menggunakan lembar kerja siswa (LKS), hal ini mengakibatkan pertanyaan yang muncul dari siswa cenderung terarah dan terdokumentasi dengan baik akan tetapi kurang fleksibel dalam proses pembelajarannya.

Berdasarkan landasan itulah, peneliti bermaksud mengkombinasikan pembelajaran bertanya tersebut dalam sebuah paket pembelajaran. Harapannya temuan di lapangan seperti kegagalan orientasi masalah (yang hakikatnya adalah orientasi pertanyaan) kepada pebelajar karena rendahnya keterampilan bertanya guru dapat direduksi.

Data empiris dari hasil Ujian Nasional SMA untuk 3 tahun terakhir (2008-2010) di Indonesia barat (termasuk Jawa Timur) menunjukkan meskipun nilai rata-rata mata pelajaran fisika tinggi, namun hasil pemetaan atas indikator SKL menunjukkan keterampilan penalaran dan berpikir siswa SMA masih rendah. Hal ini disebabkan guru kurang kompeten dalam menyusun asesmen yang berbasis higher order thinking (C4 sampai C6), guru hanya kompeten sampai pada level C3. Akibatnya keterampilan berpikir siswa masih rendah (Basuki, Ismet, dkk., 2011).

Disisi lain hakikat manusia (termasuk pebelajar) adalah pemikir. Di setiap kehidupannya pebelajar akan memikirkan sesuatu. Berbekal olah pikir (minds-on) seseorang akan bisa memaknai sesuatu. Serangkaian pertanyaan diharapkan akan membantu pebelajar melakukan olah pikir di kelas. Bahkan pembelajaran akan menjadi lebih bermakna jika dalam kegiatan belajar mengajar menyediakan "mindson/hands-on activities" (Carin, A., 1993: A-84).

Tujuan dari penelitian ini adalah: Menguji cobakan perangkat yang telah dikembangkan secara terbatas, dan selanjutnya dilakukan: 
identifikasi kompetensi-kompetensi (atribut-atribut) keterampilan berpikir siswa yang dapat ditingkatkan dengan menerapkan LBQ dalam pembelajaran Fisika, pendeskripsian potensi LBQ dalam meningkatkan keterampilan berpikir siswa, pendeskripsian respon guru model dan respon siswa dalam melaksanakan pembelajaran melalui LBQ.

Mengacu pada paradigma konstruktivisme pembelajaran, maka penelitian ini penting untuk dilakukan. Hakikat konstruktivisme dalam pembelajaran ialah konstruksi pertanyaan-pertanyaan. Selain para siswa mencoba menjawab pertanyaanpertanyaan atau memecahkan masalah, mereka juga diharapkan termotivasi untuk menciptakan pertanyaan. Pengalaman peneliti sewaktu membimbing simulasi mahasiswa fisika dan PPL 1 maupun pengamatan secara langsung di sekolah khususnya SMA, banyak guru/ calon guru yang pandai memberikan masalah dan kurang dalam keterampilan bertanya. Terdapat fakta banyak guru/ calon guru yang langsung menuliskan "rumusan

masalah: ." di papan tulis atau pada tayangan slide pada saat pembelajaran. Predikat bahwa "guru bukan pengorientasi masalah yang handal namun hanyalah pemberi masalah kepada siswa" tampaknya menjadi permasalahan dalam pembelajaran fisika. Padahal seharusnya masalah muncul dari benak siswa sebagai produk dari orientasi masalah (pemberian serangkaian pertanyaan) dari guru.

Menurut Linda Elder \& Richard Paul (2007), sebenarnya pertanyaan akan sesuatu tidak akan pernah berhenti baik dalam kehidupan maupun pembelajaran. Konstruksikonstruksi pertanyaan tidaklah mudah dilaksanakan dalam pembelajaran, namun membutuhkan rancangan (learning by design), untuk itu akan dikembangkan sebuah model pembelajaran melalui bertanya (LBQ) dalam penelitian ini. 


\section{ISSN: 2087-9946}

\section{Roadmap Penelitian}

Roadmap penelitian ini ditunjukkan pada Gambar 1.

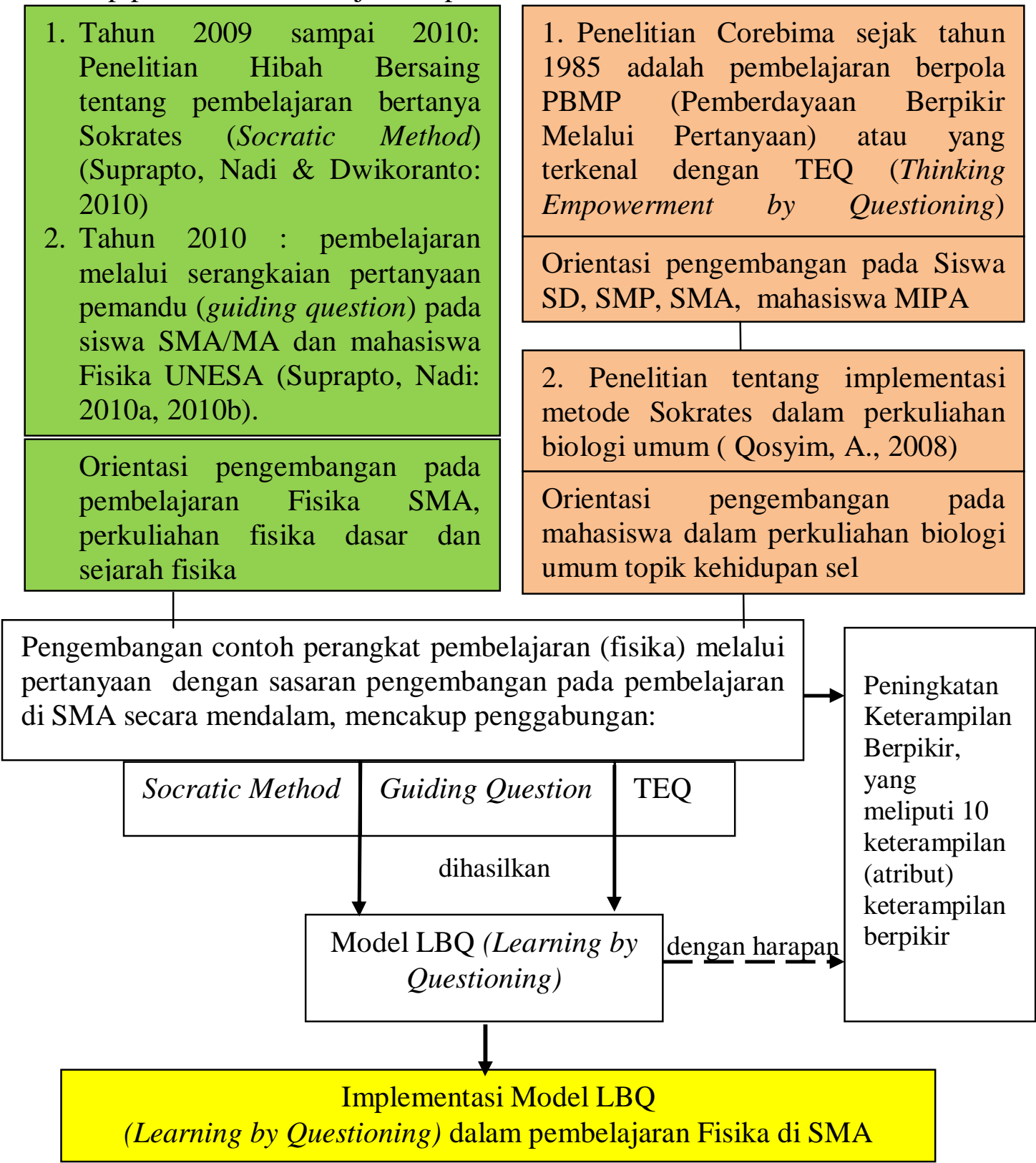

Gambar 1. Roadmap Penelitian

\section{Metode Penelitian}

Jenis penelitian yang dipilih adalah Research and Development (R\&D). Penelitian diawali dengan menghasilkan produk tertentu dan menguji keefektifan produk tersebut. Selanjutnya dilakukan pengembangan sampai diperoleh produk perangkat pembelajaran yang siap diimplementasikan. Implementasi perangkat dilakukan di SMAN 1 Gedangan Sidoarjo, sebagai sekolah binaan tim peneliti dan memungkinkan diterapkannya (adaptable) perangkat pembelajaran dalam skala uji coba terbatas. 
Penelitian dibatasi hanya pada 10 atribut keterampilan berpikir sebagaimana dikemukakan di roadmap penelitian. Pelaksanaan pembelajaran direncanakan di SMA yang memungkinkan pelaksanaan pembelajaran sesuai dengan topik/ materi yang menjadi kajian peneliti.

Instrumen penelitian yang digunakan terdiri dari: Instrumen identifikasi atribut-atribut keterampilan berpikir, Tes Keterampilan berpikir, dan Instrumen angket respon guru model dan siswa dalam pembelajaran.

Data yang dikumpulkan dari sumber-sumber validator, pengamat pembelajaran, guru mitra, dan siswa pada dasarnya dapat diklasifikasikan ke dalam jenis data atribut (baik/ sedang/ kurang baik, valid/ tidak valid, positif/ negatif, dan sejenisnya) yang terejawantahkan dalam kalimat pernyataan dan hasil-hasil penelitian. Beberapa atribut dikuantifikasi untuk memudahkan pemberian analisis. Sehingga teknik analisis data yang digunakan adalah analisis statistik deskriptif dengan persentase dan analisis logis. Statistik deskriptif digunakan untuk mengolah dan menggambarkan data ke dalam tampilan yang lebih memiliki arti dan lebih mudah dipahami, misalnya berupa bentuk tabel.

Peningkatan keterampilan berpikir siswa dihitung dengan rumus gain (g) rata-rata ternormalisasi (Savinainen \& Scott, 2002):

$$
\begin{aligned}
g= & \frac{S_{\text {post }}-S_{\text {pre }}}{100 \%-S_{\text {pre }}} \\
& S_{\text {post }} \text { dan } S_{\text {pre }} \text { adalah rata-rata }
\end{aligned}
$$
skor keterampilan berpikir siklus ke-n dan siklus sebelumnya yang dinyatakan dalam persen. Besarnya faktor-g (gain) dikategorikan sebagai berikut:

$$
\begin{array}{ll}
g>0,7 & =\text { tinggi } \\
0,3 \leq g \leq 0,7 & =\text { sedang } \\
g<0,3 & =\text { rendah }
\end{array}
$$

\section{Hasil-Hasil Penelitian dan Pembahasan}

\section{a. Hasil-hasil Penelitian}

Setelah dihasilkan contoh perangkat pembelajaran melalui pertanyaan (Learning by Questioning) yang terdiri dari dua topik fisika SMA: fluida statis yang sesuai dengan Kurikulum Tingkat satuan Pendidikan (KTSP), dan Hukum-hukum Newton sesuai dengan Kurikulum 2013. Perangkat pembelajaran tersebut terdiri atas silabus, RPP, LKS dan panduannya, buku siswa, Lembar penilaian LBQ dan kuncinya, selanjutnya diimplementasikan di kelas. Adapun terkait dengan hasil implementasi perangkat pembelajaran di kelas, diperoleh temuan-temuan:

a. Penerapan pembelajaran bertanya (LBQ) dapat meningkatkan keterampilan berpikir siswa dengan perolehan gain peningkatan untuk 10 atribut keterampilan berpikir berada pada rentang 0,27 sampai 0,73 dengan rata-rata 0,48 (sedang).

b. Ditemukan delapan atribut keterampilan berpikir ( $80 \%)$ dari sepuluh yang diteliti yang konsisten dan dapat ditingkatkan dengan pembelajaran melalui pertanyaan (LBQ). Kedelapan atribut tersebut adalah menganalisis dan mensintesis (analizing and synthesizing), meningkatkan kualitas pertanyaan (raises questions), menggali informasi (information searching), menggunakan konsep (utilizes concept), membuat inferensi (makes inferences), membangun implikasi (generates implications), mengambil keputusan (making decision), dan memecahkan masalah secara 
kreatif (creative problem solving).

c. Guru model dan siswa merespons positif pembelajaran dengan LBQ. Guru model menilai 95 persen penerapan pembelajaran LBQ sesuai untuk diterapkan, sementara siswa memberikan jawaban positif sebesar $76,7 \%$.

\section{b. Pembahasan}

Sebagaimana telah diuraikan pada bagian hasil penelitian bahwa produk penelitian ini adalah telah dihasilkan contoh perangkat pembelajaran melalui pertanyaan (Learning by Questioning) yang terdiri dari dua topik fisika SMA: fluida statis yang sesuai dengan Kurikulum Tingkat satuan Pendidikan (KTSP), dan Hukumhukum Newton sesuai dengan Kurikulum 2013. Perangkat pembelajaran tersebut terdiri atas silabus, RPP, LKS dan panduannya, buku siswa, Lembar penilaian LBQ dan kuncinya. Perangkat pembelajaran yang dikembangkan telah memenuhi validasi konstruksi dan isi sebagaimana diuraikan pada tiap komponen perangkat pembelajaran pada bagian hasil penelitian.

$$
\text { Terkait dengan hasil }
$$
implementasi perangkat, tentang peranan pembelajaran bertanya terhadap peningkatan keterampilan berpikir menunjukkan perolehan gain peningkatan untuk 10 atribut keterampilan berpikir berada pada rentang 0,27 sampai 0,73 dengan ratarata 0,48 (sedang). Perolehan tertinggi dicapai oleh siswa dalam hal menggali informasi (information searching) dan terendah pada membuat asumsi (makes assumption). Dengan kata lain terdapat delapan atribut keterampilan berpikir (80\%) dari sepuluh yang diteliti yang konsisten dan dapat ditingkatkan dengan pembelajaran melalui pertanyaan (LBQ). Kedelapan atribut tersebut adalah menganalisis dan mensintesis (analizing and synthesizing), meningkatkan kualitas pertanyaan (raises questions), menggali informasi (information searching), menggunakan konsep (utilizes concept), membuat inferensi (makes inferences), membangun implikasi (generates implications), mengambil keputusan (making decision), dan memecahkan masalah secara kreatif (creative problem solving).

Melalui pembelajaran bertanya, keterampilan siswa dalam hal meningkatkan kualitas pertanyaan (raises questions) meningkat 72 persen. Pembelajaran melalui pemberian pertanyaan menjembatani siswa aktif menjawab pertanyaan-pertanyaan yang memacu timbulnya pertanyaanpertanyaan baru. Hal tersebut nampaknya berhubungan dengan semakin berkembangnya penalaran siswa. Hal ini sejalan dengan pernyataan Zubaidah dkk.( 2001), melalui pertanyaan dapat dikembangkan kemampuan berpikir (kritis), yang merupakan salah satu ciri dari berkembangnya penalaran formal.

Sebenarnya, pertanyaan yang memicu siswa untuk mengasah keterampilan berpikir ada 3 yaitu pertanyaan literal, pertanyaan inferensial dan pertanyaan metakognitif (Fusco, Esther, 2012). Dalam penelitian ini baru dikembangkan pada level literal dan inferensial, sementara level metakognitif baru sebatas latihan awal. Pertanyaan literal adalah pertanyaan yang sering disebut "closed-ended questions" atau digunakan untuk pertanyaan akhir dan penutup karena pertanyaan ini membutuhkan satu jawaban benar. Pertanyaan yang berisi tentang fakta-fakta dan kejadian yang benar-benar ada. Pertanyaan literal mengacu pada fakta-fakta yang ada dan membutuhkan contoh-contoh yang 
konkret. Jawaban dari pertanyaan literal hanya terdapat satu jawaban.

Sebaliknya,

pertanyaan inferensial atau pertanyaan interpretasi dapat mempunyai banyak jawaban dan biasanya siswa sering menduga, mengambil kesimpulan dan mengaitkannya dengan referensi. Pertanyaan inferensial disebut dengan "open-ended questions" karena tidak hanya satu jawaban dari siswa karena mereka mempunyai berbagai macam alasan. Dengan pertanyaan inferensial siswa akan dilatihkan untuk mengembangkan pertanyaan-pertanyaan lain dari satu pertanyaan yang telah diberikan oleh guru. Pertanyaan inferensial membutuhkan jawaban yang memerlukan petunjuk yang berhubungan. Biasanya pertanyaan ini harus lebih teliti untuk menjawabnya karena bisa lebih dari satu jawaban yang benar. Pada saat membaca, untuk menjawab pertanyaan inferensial tidak dapat ditemukan pada buku, tetapi didukung oleh fakta-fakta pada buku. Untuk menjawab pertanyaan inferensial didukung dengan pertanyaan mengapa dan bagaimana. Oleh karena itu strategi pembelajaran yang berbasis pertanyaan sangat baik apabila diterapkan dalam kegiatan pembelajaran dan digunakan untuk mengasah keterampilan berpikir siswa khususnya pada pertanyaan inferensial. Sedangkan untuk pertanyaan literal mengasah daya ingat siswa.

Selanjutnya adalah pertanyaan dengan level metakognitif. Guru harus merencanakan pertanyaan dengan level metakognitif, yang mana menganjurkan siswa untuk membayangkan atau menggambarkan proses berpikir dan proses belajarnya. Untuk mengetahui proses berpikir mereka, siswa harus membangun kemampuan kognitif yang mereka miliki. Semua pertanyaan tidak hanya dijawab oleh satu siswa saja melainkan bisa lebih dari satu siswa. Siswa dapat berpikir dengan jangka waktu yang panjang dan menjawab secara bersama-sama. Direncanakan melalui penelitian lanjutan, level pertanyaan yang dikembangkan akan sampai pada tingkat metakognitif. Meskipun keterampilan berpikir yang berhasil ditingkatkan dalam pembelajaran sudah sampai pada mengambil keputusan (making decision), dan memecahkan masalah secara kreatif (creative problem solving) namun dari prosesnya belum mencapai metakognisi siswa.

Terkait dengan tanggapan atau respons guru model dan siswa menunjukkan hasil yang positif. Guru model merespon positif atau sebesar 95 persen penerapan pembelajaran LBQ sementara mayoritas siswa memberikan respons yang positif dengan persentase jawaban ya terhadap seluruh butir aspek penilaian adalah sebesar $76,7 \%$. Hasil ini jika dibandingkan dengan persentase jawaban ya yang dikemukakan oleh guru model ada perbedaan yang cukup signifikan atau sekitar $18 \% \quad(95 \%$ berbanding 76,7\%). Artinya reliabilitas jawaban siswa maupun jawaban guru masih perlu dikonfirmasi lagi.

Ke depannya fokus penelitian adalah mengimplementasikan perangkat dalam skala luas (tempat lain, sekolah lain) dan melakukan produksi massal. Untuk itu akan dilakukan validasi empiris terkait konfirmasi, klarifikasi, dan konsistensi variabel yang telah diperoleh pada ujicoba terbatas pada tahun pertama. Selain itu juga mempertimbangkan siklus pertanyaan atau Questioning Cycle, seperti Gambar 2 ini. 


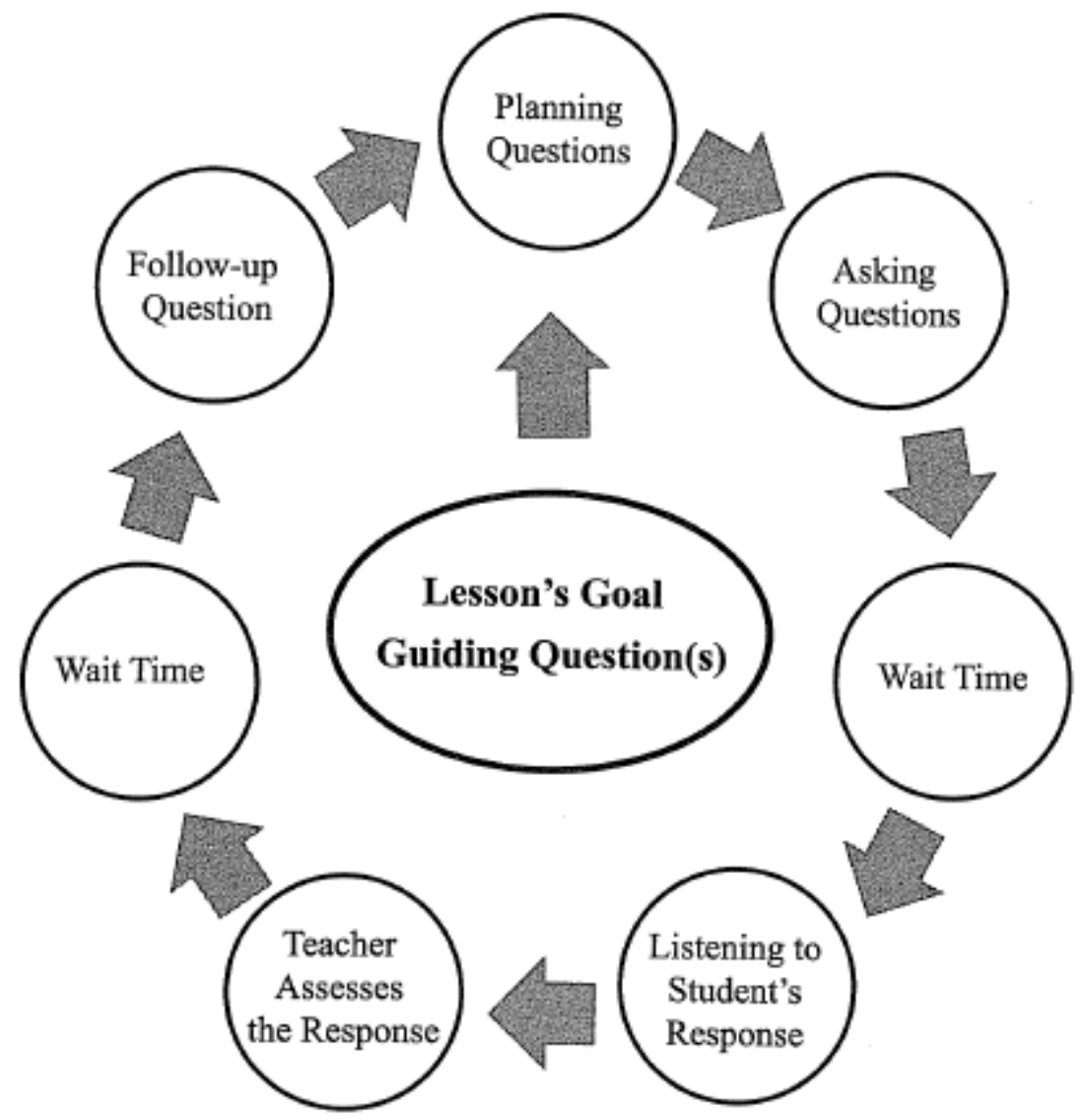

Gambar 2 langkah-langkah siklus pertanyaan (Fusco, Esther, 2012).

\section{Simpulan dan Saran}

\section{a. Simpulan}

Berdasarkan hasil dan pembahasan maka simpulan penelitian ini yaitu:

1) Telah dihasilkan contoh perangkat pembelajaran melalui pertanyaan (Learning by Questioning) yang terdiri dari dua topik fisika SMA: fluida statis yang sesuai dengan Kurikulum Tingkat satuan Pendidikan (KTSP), dan Hukum-hukum Newton sesuai dengan Kurikulum 2013. Perangkat pembelajaran tersebut terdiri atas silabus, RPP, LKS dan panduannya, buku siswa, Lembar penilaian LBQ dan kuncinya.

2) Terkait dengan hasil implementasi perangkat pembelajaran di kelas, diperoleh temuan-temuan:

a) Penerapan pembelajaran bertanya (LBQ) dapat meningkatkan keterampilan berpikir siswa dengan perolehan gain peningkatan untuk $\quad 10 \quad$ atribut keterampilan berpikir berada pada rentang 0,27 sampai 0,73 dengan ratarata 0,48 (sedang). 
b) Ditemukan delapan atribut keterampilan berpikir $(80 \%)$ dari sepuluh yang diteliti yang konsisten dan dapat ditingkatkan dengan pembelajaran melalui pertanyaan (LBQ). Kedelapan atribut tersebut adalah menganalisis dan mensintesis (analizing and synthesizing),

meningkatkan kualitas pertanyaan (raises questions), menggali informasi (information searching), menggunakan konsep (utilizes concept), membuat inferensi (makes inferences), membangun implikasi (generates implications), mengambil keputusan (making decision), dan memecahkan masalah secara kreatif (creative problem solving).

c) Guru model dan siswa merespons positif pembelajaran dengan LBQ. Guru model menilai 95 persen penerapan pembelajaran LBQ sesuai untuk diterapkan, sementara siswa memberikan jawaban positif sebesar $76,7 \%$.

\section{b. Saran}

Berdasarkan temuan, simpulan, dan kekurangan dalam penelitian maka dituliskan beberapa saran dalam penelitian ini:

1. Perlunya pengembangan pertanyaan metakognitif dalam finalisasi peragkat pembelajaran selanjutnya, yang dalam penelitian ini baru dikembangkan pada level literal dan inferensial, sementara level metakognitif baru sebatas latihan awal.
2. Sesuai dengan perencanaan maka pada penelitian lanjutan perlu mendeskripsikan aktivitas guru dan siswa

3. Perlunya melakukan validasi empiris terkait konfirmasi, klarifikasi, dan konsistensi variabel yang telah diperoleh pada ujicoba terbatas pada tahun pertama. Sebagai ilustrasi pada penelitian ini diperoleh perbedaan angka respons yang dikemukakan oleh guru maupun siswa.

4. Selain itu juga perlu mempertimbangkan siklus pertanyaan atau Questioning Cycle.

\section{Ucapan Terima Kasih}

Ucapan terima kasih kepada DP2M Ditjen Dikti atas didanai penelitian ini dari Skim Penelitian Desentralisasi (Hibah Bersaing) tahun 2013 berdasarkan SPK Nomor: 024/UN.38.11-P/LT/2013, tanggal 11 Februari 2013.

\section{Daftar Pustaka}

[1] Basuki, Ismet, dkk. 2011. "Pemetaan dan Pengembangan Mutu Pendidikan Sekolah Menengah Atas di Wilayah Indonesia Barat". Laporan Penelitian Pemetaan dan Pengembangan Mutu Pendidikan Tahun Anggaran 2011. Lemlit UNESA.

[2] Bunce, D. M. 1996. The Quiet Revolution in Science EducationTeaching Science The Way Students Learn. Journal of College Science Teaching, XXV (3): 169-171.

[3] Carin, Arthur A. 1993. Teaching Science Through Discovery. New York: Macmillan Publishing Company.

[4] Crown, L. W. 1989. The Nature of Critical Thinking. Journal of 
College Science Teaching, Nopember: 114-116.

[5] Dahar, Ratna Wilis. 1988. Teoriteori Belajar. Jakarta: Proyek Pengembangan LPTK.

[6] Elder, Linda \& P. Richard. 2007. Analytic Thinking (How to take thinking apart and what to look for when you do). The Foundation for critical thinking, retrieved from www.criticalthinking.org.

[7] Fusco, Esther. 2012. Effective Questioning Strategies in the Classroom. New York: Teachers College, Columbia University.

[8] Qosyim, Achmad. 2007. Metode Sokrates (Sokratic Method). Studi Implikasi Metode Sokrates dalam Praktek Pendidikan (makalah tidak dipublikasikan).

[9] Qosyim, Achmad. 2008. "Pengembangan Perangkat Pembelajaran Biologi Untuk Perguruan Tinggi Yang Berorientasi Pada Metode Sokrates" (Tesis Tidak dipublikasikan). Pascasarjana UNESA.

[10] Savinainen, A \& Scott, P. 2002. The Force Concept Inventory: A Tool for Monitoring Student Learning. Physics Education. 37(1), 45-52.

[11] Suprapto, Nadi. 2010a. "Penerapan guiding question pada topik-topik Fisika Modern sebagai upaya meningkatkan pemahaman konsep siswa akselerasi (MA Amanatul Ummah Pacet Mojokerto)". Artikel dalam Prosiding Seminar Nasional Pengembangan dan Pembelajaran Fisika tanggal 22
Mei 2010 yang diselenggarakan oleh Jurusan Fisika Unesa dengan No. ISBN 978-979-028-329-9

[12] Suprapto, Nadi. 2010b. "Pemberian guiding question pada model guided discovery sebagai upaya meningkatkan kinerja praktikum dan pemahaman konsep fisika mahasiswa". Artikel dalam Prosiding Seminar Nasional Sains 2010 yang diselenggarakan oleh Prodi Pendidikan Sains PPs Unesa tanggal 16 Januari 2010 dengan No. ISBN 978-979-028-272-8.

[13] Suprapto, Nadi. \& Dwikoranto 2010. "Kajian empiris pengembangan perangkat pembelajaran model sokrates pada mata kuliah Sejarah Fisika". Artikel dalam Seminar Nasional Hasil-hasil Penelitian yang diselenggarakan oleh Lemlit Unesa tanggal 22 Nopember 2010 di Hotel Inna Simpang Surabaya.

[14] Woods, D. R. 1996. Teaching and Learning: What Can Research Tell Us? Journal of College Science Teaching, XXV (3):229232.

[15] Yager, R. E. dan Huang, Dar-Sun. 1994. An Alternative Approach to College Science Education for Nonscience Majors. Journal of College Science Teaching, November: 98-100.

[16] Zubaidah, Siti. 2010. "Pemberdayaan Berpikir Melalui Pertanyaan". Artikel diakses dari http://desainwebsite.net/pendidika n/pemberdayaan-berpikir-melaluipertanyaan, diunduh pada 31 Januari 2011. 